\title{
PANDANGAN DUNIA PENGARANG DALAM KUMPULAN PUISI BLUES UNTUK BONNIE KARYA RENDRA (KAJIAN STRUKTURALISME GENETIK)
}

\author{
Annisa Lastari \\ SMA Annur Bekasi \\ E-mail: annisalastari17@gmail.com
}

\begin{abstract}
ABSTRAK
Penelitian ini bertujuan mengetahui pandangan dunia pengarang dalam kumpulan puisi karya Rendra dengan menggunakan teori strukturalisme genetik Goldmann. Metode penelitian ini yaitu deskriptif kualitatif. Kesimpulan penelitian ini yaitu pandangan dunia pengarang meliputi tiga hal, yaitu enam puisi berisi penggambaran sosial politik di Indonesia dan Amerika yaitu Kupanggili Namamu, Blues untuk Bonnie, Kesaksian Tahun 1967, Pemandangan Senjakala, Bersatulah Pelacur-pelacur Kota Jakarta, dan Pesan Pencopet kepada Pacarnya; lima puisi berisi pelanggaran manusia terhadap nilainilai susila dan kebudayaan: Kepada M.G, Nyanyian Duniawi, Nyanyian Suto untuk Fatima dan Nyanyian Fatima untuk Suto, Rick dari Corona; dan dua puisi berisi kritik terhadap lembaga agama: Nyanyian Angsa dan Khotbah.
\end{abstract}

Kata kunci: puisi, strukturalisme genetik, Blues untuk Bonnie, Rendra

\section{THE AUTHOR'S WORLD VIEW IN BLUES UNTUK BONNIE BY RENDRA (GENETIC STRUCTURALISM STUDY)}

\begin{abstract}
This research aims to find out the author's world view in Rendra's poetry collection using the theory of genetic structuralism by Goldmann. This research method is descriptive qualitative. The conclusion of this research is that the author 's world view covers three things, namely six poems containing the social and political representation in Indonesia and America: Kupanggili Namamu, Blues untuk Bonnie, Kesaksian Tahun 1967, Pemandangan Senjakala, Bersatulah Pelacur-pelacur Kota Jakarta, and Pesan Pencopet kepada Pacarnya, five poems containing human infringement against ethical values and culture: Kepada M.G, Nyanyian Duniawi, Nyanyian Suto untuk Fatima dan Nyanyian Fatima untuk Suto, Rick dari Corona; and two poems containing criticisms of religious institutions: Nyanyian Angsa and Khotbah.
\end{abstract}

Keywords: poetry, genetic structuralism, Blues untuk Bonnie, Rendra

AKSIS: Jurnal Pendidikan Bahasa dan Sastra Indonesia

Volume 1 Nomor 1, Juni 2017 e-ISSN: 2580-9040

e-Journal: http://doi.org/10.21009/AKSIS 


\section{PENDAHULUAN}

Puisi-puisi yang sejati, yang merupakan hasil kreativitas, merupakan gambaran bagaimana pikiran dan perasaan seseorang bergerak saat bersentuhan dengan realitas kehidupan. Meskipun demikian tidak banyak penyair yang dapat merekam realitas kehidupan yang ada di sekitarnya dan menuangkannya ke dalam puisi. Imajinasi dan keinginan yang terlalu menggebu-gebu seringkali terlalu mendominasi, sehingga karya yang dihasilkan tidak otentik dan terlalu dibuat-buat. Melalui karya dapat dilihat bagaimana pandangan dunia penyair ketika dihadapkan pada suatu persoalan. Salah satu dari sekian banyak penyair yang mampu menuangkan pikiran, perasaan, bahkan realitas dengan baik dalam bentuk puisi ialah Rendra.

Rendra atau lengkapnya Willibrodus Surendra merupakan salah seorang sastrawan Indonesia yang telah menghasilkan banyak karya dan prestasi. Rendra lahir pada tanggal 7 November 1935 di Solo. Ibunya seorang penari Serimpi di Keraton Kesultanan Yogyakarta, sedangkan ayahnya seorang guru Bahasa Indonesia dan Jawa Kuno di SMA Kanisius Solo. Ia besar dalam lingkungan adat Jawa yang kental, di samping ia juga dibesarkan dengan ajaran Katolik ortodoks. Karya sastra pertama yang ditulisnya yaitu puisi berjudul Ulang Tahun yang Ketiga Belas yang ditulisnya ketika masih di bangku SMP. Setelahnya Rendra bukan hanya menulis puisi, tetapi juga produktif dalam menulis naskah drama dan beberapa cerpen, selain itu ia juga menjadi sutradara pementasan teater bahkan bermain di beberapa film. Rendra dapat dikatakan termasuk penyair besar karena karyanya selalu memuat empat hal sekaligus, yaitu: memperlihatkan ciri-ciri individualisme, originalitas, kepekaan terhadap sekitar, dan mampu menampilkan gaya bahasa yang khas.

AKSIS: Jurnal Pendidikan Bahasa dan Sastra Indonesia 
Kumpulan puisi pertama Rendra yaitu Ballada Orang-Orang Tercinta (BOT) ia ciptakan ketika ia masih berumur 22 tahun atau lebih muda dari itu, sehingga wajar jika saat itu puisi-puisinya belum menunjukkan sikap hidup yang matang. Meskipun sudah menunjukkan perhatian terhadap orang-orang terpinggirkan seperti gelandangan, ibu yang ditinggal anaknya, maupun kaum tersisih, tetapi pandangannya terhadap lingkungan danmasyarakatnya masih bersifat naif. Hal ini bisa dilihat dari bagaimana Rendra melihat orang-orang di sekitarnya hanya dengan kaca mata hitam putih. Puisipuisinya mengandung nada sentimental yang walaupun tidak berlebih-lebihan terkesan terlalu polos. Pada kumpulan sajaknya yang kedua, Empat KumpulanSajak, percintaan menjadi tema yang dominan. Hal tersebut disebabkan saat itu Rendra tengah menikmati cinta pertama dengan Sunarti, yang kelak menjadi istri pertamanya. Pembicaraan mengenai dunia yang dikenalnya dalam kumpulan ini tampak masih digambarkan jauh dari kehidupan yang serba pahit ataupundisertai konflik yang kompleks.

Perubahan terlihat ketika terbit kumpulan puisi ketiga Blues untuk Bonnie (BUB). Ketika kepergiannya ke Amerika antara tahun 1964 hingga tahun 1967 Rendra menulis sekitar sembilan sajak dan merevisi dua sajak yang ia tulis pada tahun 1958. Kemudian ia menerbitkan dua sajak yang ia tulis di Yogyakarta. Ketiga belas sajak inilah yang kemudian dihimpun dalam BUB dan diterbitkan pada tahun 1971. Kumpulan ini terdiri ataspuisi Kupanggili Namamu (1964), Blues untuk Bonnie (1964), Kepada M.G. (1964), Rick dari Corona (1966), Pemandangan Senja Kala (1967), Nyanyian Duniawi (1966), Bersatulah Pelacur-Pelacur Kota Jakarta (1967), Nyanyian Angsa (1967), Pesan Pencopet kepada Pacarnya (1967), Khotbah (1967), Kesaksian Tahun 1967 (1967), Nyanyian Suto untuk Fatima (1968), dan Nyanyian Fatima untuk Suto (1968). Secara garis besar, latar dalam Blues untuk Bonnie dipengaruhi oleh 
kehidupan modern masyarakat Amerika, dan sebagian lainnya yaitu puisi yang mengangkat latar Indonesia.

Adanya perubahan tema dari waktu ke waktu menunjukkan bahwa terdapat perbedaan pandangan dunia yang ditampilkan pengarang dalam setiap karyanya. Melalui karyanya dapat diketahui bagaimana pandangan dunia pengarang pada waktu dan kondisi tertentu. Pandangan dunia yang terdapat dalam Ballada Orang-orang Tercinta, Empat Kumpulan Sajak, dan Blues untuk Bonnie tentu berbeda karena dibuat pada waktu yang berbeda dan mengangkat persoalan yang berbeda pula. Untuk dapat mengetahui pandangan dunia pengarang yang muncul pada suatu karya tentu terlebih dahulu diketahui waktu dan kondisi pada saat karya tersebut diciptakan. Sebagai pemeriksaan awal, kumpulan puisi Blues untuk Bonnie diciptakan pada tahun-tahun yang bersamaan dengan peristiwaperistiwa penting. Dengan meneliti kumpulan puisi Blues untuk Bonnie dapat diketahui pandangan dunia Rendra terhadap kondisi masyarakatnya. Pandangan dunia yang terdapat dalam sebuah karya sastra sekaligus merupakan pandangan secara kolektif dari anggota masyarakat.

Ketika Rendra berangkat ke Amerika pada pertengahan tahun 1960 baik Amerika maupun Indonesia sedang berada dalam puncak perubahan sosial. Indonesia berada dalam fase-fase penting runtuhnya kekuasaan Orde Lama dan dimulainya rezim Orde Baru. Diawali tragedi G30S yang terjadi pada tahun 1965, kekuasaan tertinggi pemerintahan Indonesia beralih dari Soekarno ke tangan Soeharto. Pada saat yang sama, Amerika yang juga tengah berada dalam fase perubahan sosial besar-besaran. Berbagai persoalan menyangkut diskriminasi ras, revolusi seks, dan kontrakultur mengganggu keseimbangan negara adidaya Negara Amerika. Pada masa demikianlah Rendra menciptakan puisi-puisi yang terhimpun dalam $B U B$. Maka tak heran jika puisi-puisinya 
bersangkut paut dengan permasalahan di kedua negara tersebut. Rendra sendiri merupakan salah satu tokoh yang ikut andil dalam perubahan sosial tersebut karena kepenyairannya yang mulai mendapat perhatian masyarakat, selain juga karena ia tergabung dalam sastrawan sayap kanan yang menandatangani Manifesto Kebudayaan.

Kajian lain yang menunjukkan bahwa $B U B$ mengangkat persoalan masyarakat adalah tulisan Harry Aveling yang berjudul Sang Penyair di New York: Beberapa Sajak Terbaru W.S Rendra. Ia mengatakan bahwa puisi-puisi dalam $B U B$ mengandung sisi realisme romantik. Realisme romantik mengacu pada kecenderungan mengangkat realitas di kota-kota besar dengan memusatkan perhatian terhadap kaum terpinggir dan tertindas di kota. Dalam $B U B$ kota besar modern yang dimaksud yaitu Jakarta, Yogyakarta, New York, dan Boston. Selain itu, dijelaskan pula mengenai wanitawanitanyasebagai berikut, di dalamnya para wanita cenderung dijadikan korban sambil dijadikan orang suci dalam kepasifan dan penyerahannya yang Kristiani; sedang para lelaki aktif, agresif, ganas, suka merampas, mereka "sungguh-sungguh" kaum cerdik yang jahat.

Alasan lain yang menjadikan Rendra memiliki peran penting dalam dunia sastra ialah karena ia dikenal sebagai sastrawan yang mengenalkan gaya balada di Indonesia. Sebelumnya gaya puisi lirik mendominasi dalam kesusastraan Indonesia. Gaya balada menjadi menarik karena memiliki sifat naratif atau berkisah, maka di dalamnya terdapat tokoh, alur dan latar sebagaimana dimiliki oleh cerita. Selain itu, salah satu yang menjadi ciri khas Rendra dalam mencipta adalah gaya bahasa yang ia gunakan. Berdasarkan tulisan Pradopo (2002) yang berjudul Penelitian Stilistika Genetik: Kasus Gaya Bahasa Rendra dalam Ballada Orang-Orang Tercinta dan Blues untuk Bonnie dikemukakan bahwa gaya bahasa kata yang paling dominan digunakan Rendra ialah 
kiasan dan citraan. Sebagai tahap awal untuk memahami struktural puisi-puisi Rendra dapat dilakukan dengan mengungkap makna kata kiasan dan citraan yang digunakan Rendra dalam kumpulan puisi $B U B$. Dengan demikian, akan lebih mudah memahami makna yang terkandung dalam puisi, bukan hanya makna pada permukaannya saja.

Namun, sebuah karya tidak dapat berdiri sendiri, karenanya untuk dapat mengkajinya tidak dapat dilihat hanya berdasarkan teksnya (struktural) saja. Pemahaman terhadap karya sastra harus mempertimbangkanstruktur teks dan pengarang (Teeuw, 2016). Unsur pengarang menjadi penting karena sebuah karya sastra menampung pandangan, harapan, dan pemikiran pengarangnya. Harapan, cita-cita dan pandangan tersebut bisa terbentuk berdasarkan norma-norma sosialmasyarakat tempat pengarang berada (Saini, 1993). Latar semacam itu memiliki tendensi yang kuat dalam mempengaruhi penciptaan karya sastra.

Strukturalisme genetik menunjukkan hubungan antara alam ciptaan pengarang dengan perlengkapan sastra yang dipergunakan pengarang untuk melukiskannya (Damono, 1984). Pada hakikatnya strukturalisme genetik bertujuan menemukan pandangan pengarang dalam karya sastra. Pendekatan ini lahir karena adanya ketidakpuasan terhadap kajian struktural yang antihistorial dan hanya menitikberatkan terhadap unsur intrinsik saja, sehingga dirasa perlu untuk mengkaji latar historis ketika puisi diciptakan. Oleh karena itu, dalam struktural genetik unsur yang dikaji meliputi unsur intrinsik dan juga unsur ekstrinsik karya sastra.

Keunggulan strukturalisme genetik dibandingkan dengan teori lain dalam mengkaji karya sastra yaitu karena pendekatan ini dibangun oleh pendekatan, teori, konsep, metode dan teknik yang memenuhi kaidah penelitian ilmiah. Selain itu, kajian strukturalisme genetik dianggap memiliki kekuatan dalam penelitian sosiologi sastra 
karena strukturalisme genetik mempunyai dasar teori yang jelas dan tetap memberikan tekanan kepada nilai karya sastra (Junus, 1974). Keistimewaan lain, strukturalisme genetik hanya mengkhususkan kajiannya terhadap karya sastra utama, yaitu karya sastra yang merupakan master piece dari pengarangnya. BUB memenuhi kualifikasi tersebut,karena selain Rendra adalahseorangsastrawan yang diakui di Indonesia, $B U B$ juga merupakan karya yang dihasilkan pada puncak kepenyairan Rendra (Pradopo, 2002), selain juga diciptakan ketika berlangsungnya perubahan sosial di kedua negara yang ditinggali Rendra antara tahun 1960 hingga 1970.

Secara spesifik, strukturalisme genetik yang diterapkan dalam kajian ini adalah strukturalisme genetik berdasarkan teori Goldmann. Goldman membagi kategorikategori yang saling bertalian dalam menerapkan penerapan teori struktural genetik, yaitu fakta kemanusiaan,subjek kolektif, pandangan dunia pengarang, dan konsep pemahaman dan penjelasan.

Kajian menggunakan pendekatan struktural genetik terhadap puisi memang belum banyak dilakukan. Hal ini disebabkan karena kajian strukturalisme genetik hanya bisa digunakan pada teks-teks yang bersifat naratif, sedangkan pada umumnya puisi karya penyair-penyair Indonesia berwujud puisi lirik. Namun, pemilihan analisis strukturalisme genetik terhadap puisi karya Rendra tepat, karena dilihat dari wujudnya puisi-puisi karya Rendra mengandung unsur balada atau sajak berkisah. Seperti telah disebutkan di atas, dalam karya-karyanya Rendra menciptakan semesta tokoh-tokoh lengkap dengan dunianya. Dalam puisi-puisinya Rendra selalu dapat menampilkan Problematic hero atau tokoh yang berhadapan dengan persoalan-persoalan yang besar. Hal tersebut juga menjadi alasan kuat puisi dalam Blues Untuk Bonnie dapat dikaji dengan strukturalisme genetik.

AKSIS: Jurnal Pendidikan Bahasa dan Sastra Indonesia Volume 1 Nomor 1, Juni 2017 e-ISSN: 2580-9040 
Selain itu, keunggulan penelitian ini antara lain belum pernah ada kajian terhadap kumpulan puisi Blues Untuk Bonnie dengan menggunakan pendekatan strukturalisme genetik. Adapun penelitian menggunakan strukturalisme genetik terhadap karya Rendra antara lain dilakukan oleh Ahmad Zaim dalam skripsinya berjudul Pandangan Dunia dalam Naskah Drama Kisah Petualangan Suku Naga. Sedangkan penelitian terhadap Blues untuk Bonnie yang melibatkan unsur genetic pernah juga dilakukan oleh Sapardi Djoko Damono, tetapi penelitian tersebutmenekankan pada stilistika genetik yaitu berjudul Penelitian Stilistika Genetik: Kasus Gaya Bahasa W.S Rendra dalam Ballada Orang-orang Tercinta dan Blues untuk Bonnie.

Dengan mengetahui bagaimana keadaan sosial masyarakat dapat memberikan inspirasi bagi seorang penyair dalam menciptakan puisi, maka menulis puisi menjadi lebih mudah dilakukan. Pembelajaran mengenai proses kreatif menulis puisi sendiri merupakan salah satu materi yang terdapat dalam kurikulum pembelajaran di sekolah. Dengan mempelajari bagaimana seorang penyair dapat menuangkan apa yang terdapat di sekitarnya dan mempengaruhi pandangannya untuk kemudian menjadi sebuah puisi, siswa dapat termotivasi untuk belajar membuat puisi dengan lebih menyenangkan. Dengan demikian siswa tidak lagi merasa bahwa membuat puisi hanyalah berdasarkan kekuatan imajinasi, tetapi bisa juga dengan mengasah kepekaan terhadap lingkungan. Dengan demikian, pembelajaran menulis puisi tidak lagi menakutkan bagi siswa karena dianggap terlalu sulit. Selain itu, dengan menulis puisi siswa dilatih untuk lebih peka terhadap lingkungan sekitarnya selain juga menyeimbangkan faktor dalam dirinya dengan menyampaikan aspirasi, gagasan, dan perasaan melalui puisi.

AKSIS: Jurnal Pendidikan Bahasa dan Sastra Indonesia 


\section{METODE}

Dalam penelitian ini metode yang digunakan adalah metode dialektik yang diutarakan oleh Goldmann. Cara kerja teknik dialektik menggunakan dua pasangan konsep yaitu "keseluruhan-bagian" dan "pemahaman-penjelasan". Konsep "keseluruhan-bagian" merupakan cara yang digunakan untuk meneliti struktur keseluruhan dari sebuah karya sastra berdasarkan struktur internalnya. Adapun pemahaman adalah usaha mendeskripsikan struktur objek yang dipelajari, sedangkan penjelasan adalah usaha penemuan makna struktur itu dengan menggabungkan ke dalam struktur yang lebih besar. Langkah analisis dalam penelitian ini adalah: (1) memaparkan fakta kemanusiaan empiris (struktur sosial masyarakat) yang terjadi pada saat puisi diciptakan, (2) mengkaji struktur intrinsik yang menbangun puisi, (3) memaparkan struktur karya sastra, (4) menghubungkan fakta kemanusiaan dan subjek fakta kemanusiaan dalam struktur masyarakat dengan struktur sosial yang terbangun di dalam teks, (5) menganalisis untuk menentukan pandangan dunia pengarang yang terdapat dalam kumpulan puisi Blues untuk Bonnie karya Rendra.

\section{HASIL DAN PEMBAHASAN}

Berdasarkan keadaan sosial masyarakat antara tahun 1960 hingga 1970 baik di Amerika maupun Indonesia dan analisis struktural puisi dalam Blues untuk Bonnie, berikut adalah analisis mengenai pandangan dunia pengarang dalam kumpulan puisi Blues untuk Bonnie. Pada bagian ini dapat dilihat hubungan antara struktur karya sastra dengan keadaan sosial masyarakat yang telah dituliskan sebelumnya sehingga dapat ditemukan pandangan dunia pengarang dalam kumpulan puisi Blues untuk Bonnie.

AKSIS: Jurnal Pendidikan Bahasa dan Sastra Indonesia 
Puisi Kupanggili Namamu dibuat pada tahun 1964, tahun yang sama dengan kepergian Rendra ke Amerika. Melalui puisi ini Rendra menggambarkan keadaan dirinya yang sedang merindukan tanah airnya, Indonesia. Pemberontakan terhadap rumah yang disinggung-singgung Rendra dalam puisi ini tidak lain merujuk kepada sebabnya meninggalkan Indonesia. Kepenyairan Rendra pada masa Orde Lama mendapat banyak hambatan karena dianggap tidak sesuai dengan kebutuhan politik dan masyarakat pada masa itu. Rendra menunjukan sikap memperjuangkan hak kebebasan individu dalam berkarya. Hal ini bertentangan dengan ideologi Lembaga Kebudayaan Rakyat, organisasi yang mendapat dukungan besar dari pemerintah yang berkuasa. Lembaga Kebudayaan Rakyat merupakan organisasi yang menghimpun sastrawan sayap kiri yang mengusung slogan 'seni sebagai panglima politik'. Organisasi ini berlawanan dengan ideologi sastrawan sayap kanan yang berbunyi 'seni untuk seni'. Pertentangan pandangan antara sastrawan sayap kanan dengan Lembaga Kebudayaan Rakyat menjadi salah satu alasan kepergian Rendra ke Amerika sebagaimana telah disinggung sebelumnya. Rendra kemudian memutuskan untuk menimba ilmu teater secara lebih mendalam di Amerika.

Rendra berangkat dari hal yang sederhana di awal puisi ini dengan membicarakan kerinduannya terhadap negara yang ia tinggalkan. Kepergiannya bukanlah sematasemata karena ia ingin belajar drama di Amerika, melainkan juga karena memang keadaan yang tidak memungkinkan baginya tetap tinggal di Indonesia. Melalui puisi ini Rendra membagi pengalaman, pandangan dan perasaannya yang jauh dari tempatnya negara yang ia cintai.

Pandangan dunia pengarang dalam puisi Kepada M.G, pandangan Rendra, mengenai puisi ini konsisten bila dilihat dalam tulisan-tulisannya dari waktu ke waktu, 
dan ia teguh berpendapat bahwa ini adalah gejala budaya. Dalam konteks waktu dan peristiwa yang melatarbelakangi pembuatan puisi ini seperti telah dibahas sebelumnyadalam sub-bab konteks sosial masyarakat Amerika dapat dilihat pakempakem budaya yang berusaha dilanggar dengan perlawanan serupa yang dilakukan 'Aku' dan M.G. Hal ini dalam adalah sebagai upaya manusia mencari makna kebebasan individu. Namun bagi Rendra hal tersebut bukanlah sesuatu yang dapat dibenarkan.

Pandangan dunia pengarang dalam puisi Nyanyian Duniawi, pandangan Rendra, memperlihatkan salah satu caranya memberontak terhadap kemelaratan yang dialami masyarakat miskin Indonesia di antaranya dengan dengan melakukan pelanggaran semacam percintaan terlarang. Hal sederhana yang mendatangkan kebahagiaan sebagaimana dirasakan kedua tokoh tersebut.

Pandangan dunia pengarang dalam puisi Nyanyian Suto untuk Fatima dan puisi Nyanyian Fatima untuk Suto, menunjukan kritik terhadap hal tersebut meskipun tidak secara jelas menyinggung adat budaya Jawa sebagai latar. Namun, melihat kesamaan cara pandang Rendra dan fakta bahwa Rendra selalu konsisten dengan cara pandangnya tentu dapat dipahami pandangan Rendra yang berusaha diutarakan melalui puisi ini.

Pandangan dunia pengarang dalam Puisi Blues untuk Bonnie, melalui puisi ini pengarang membagi pandangannya tentang realitas yang ia lihat dalam diri masyarakat Amerika. Ia begitu cermat mengamati lingkungannya yang saat itu sedang berada dalam fase perubahan sosial. Ketika Rendra tinggal di Amerika antara 1964-1967 pada saat itu isu tentang diskriminasi kaum hitam memang sedang marak-maraknya. Negro Tua tak lain sebagai gambaran nyata dari kaum Afro-Amerika yang mengalami kehidupan sulit di tanah Amerika. Penggambaran mengenai kehidupan Negro Tua tersebut juga sesuai dengan kehidupan Afro-Amerika di Amerika secara umum. 
Pandangan dunia pengarang dalam puisi Rick dari Corona, Besty dalam puisi ini mewakili streotip wanita Negro jauh sebelum perubahan sosial memang dikenal banyak berprofesi sebagai pelacur di daerah asalnya. Hal ini disebabkan oleh keterbelakangan pendidikan dan kemiskinan yang mendera mereka. Pada tahun 1966 dan beberapa tahun sesudahnya keadaan mereka tidak begitu membaik, atau paling tidak begitulah streotip yang sudah terlanjur melekat dalam diri mereka. Wanita Negro dikenal suka bergantiganti pasangan dan terlibat dalam seks bebas baik sebagai pribadi maupun profesi. Pada akhir puisi ini disebutkan bahwa Ricky dan Betsy pergi ke dokter karena menderita rajasinga. Sebagai generasi muda yang menganut gaya Amerika baru dengan kebebasan seksnya, Ricky dan Betsy menanggung dampak negatifnya. Hal ini merupakan penggambaran yang terjadi ketika revolusi seks berlangsung, penyakit kelamin banyak menjangkiti generasi muda Amerika yang menganut gaya hidup bebas. Hubungan seks bebas dengan lawan jenis ataupun sejenis berdampak pada munculnya bebagai penyakit kelamin seperti yang diderita Ricky dan Betsy.

Pandangan dunia pengarang dalam puisi Kesaksian Tahun 1967 dapat dilihat konsistensi pandangan pengarang terhadap dunia yang dicermatinya. Seperti telah disinggung sebelumnya Rendra di masa Orde Baru tidak jarang mengkritik kebijakan pemerintah. Ia memosisikan dirinya sebagai penyalur aspirasi masyarakat. Hal tersebut diwujudkan antara lain melalui puisi ini.

Pandangan DuniaPengarang dalam Puisi Pemandangan Senjakala. Dalam sub-bab sebelumnya tentang kondisi sosial masyarakat Indonesia yang menjadi latar belakang kumpulan Blues Untuk Bonnie telah disebutkan bahwa kekacauan di Indonesia terkait kepentingan politik. Ada banyak versi mengenai siapa yang betanggung jawab, tetapi Rendra dalam puisi ini menyebutnya sebagai 'saudara-saudaraku'. Hal ini menunjukan 
bahwa Rendra mencurigai bahwa oknumnya tak lain berasal darinegeri sendiri. Puisi ini juga menunjukan bahwa Rendra berpandangan bahwa kekacauan tersebut sengaja diciptakan.

Pandangan Dunia Pengarang dalam Puisi Pemandangan Senjakala. Dalam subbab sebelumnya tentang kondisi sosial masyarakat Indonesia yang menjadi latar belakang kumpulan Blues Untuk Bonnie telah disebutkan bahwa kekacauan di Indonesia terkait kepentingan politik. Ada banyak versi mengenai siapa yang betanggung jawab, tetapi Rendra dalam puisi ini menyebutnya sebagai 'saudara-saudaraku'. Hal ini menunjukan bahwa Rendra mencurigai bahwa oknumnya tak lain berasal dari negeri sendiri. Puisi ini juga menunjukan bahwa Rendra berpandangan bahwa kekacauan tersebut sengaja diciptakan.

Pandangan Dunia Pengarang dalam Puisi Bersatulah Pelacur- Pelacur Kota Jakarta. Menurutnya bukan pelacuran yang lebih dahulu harus diurusi dan dijadikan persoalan melebihi yang lain sehingga para pelacur menjadi korban, melainkan para pejabat yang membiarkan terjadi kemiskinan, pengangguran, dan pelacuran yang harus lebih dulu ditindak. Perlu dipahami bahwa keberpihakan Rendra kepada kaum tersisih dan orang-orang terpinggir seperti pelacur bukan sekali ini dituliskannya dalam bentuk puisi. Dalam kumpulan-kumpulan puisi sebelumnya seperti Ballada Orang-orang Tercinta Rendra sudah menunjukan kecenderungan tersebut, seperti dikatakan Rendra “...mereka selalu muncul dalam sajak-sajak saya” Puisi ini menunjukan konsistensi pandangan dunia Rendra terhadap lingkungan dan masyarakatnya.

Pandangan dunia pengarang dalam puisi Pesan Pencopet kepada Pacarnya, penilaian Rendra berpusat kepada perilaku Kepala Jawatan hingga menteri sebagai priapria yang senang bermain serong, sogok-menyogok dan korupsi, serta tentara yang turut 
campur dalam segala sektor pemerintahan hingga hak-haknya diutamakan oleh pemerintah. Kemudian ia juga menyebutkan bahwa gaya 'maling' yang diterapkan para pejabat itulah 'ilmu selamat' yang paling tepat diterapkan di Indonesia, karena dengan begitu rakyat kecil bisa menanjak kedudukannya bahkan masuk dalam perpolitikan. Secara tidak langsung pandangan Si Pencopet tersebut tak lain juga merupakan pandangan Rendra, seperti puisi-puisi lainnya, puisi ini juga bernada menyindir lewat pandangan rakyat kecil. Bahkan kali ini Rendra bukan hanya 'menyindir' tetapi juga memberikan penilaian yang tidak main-main mengenai pejabat-pejabat Indonesia yang berada di kursi pemerintahan tahun 1967.

Pandangan dunia pengarang dalam puisi Nyanyian Angsa, Rendra dalam puisi ini tetap menunjukan kepercayaan dan kesetiannya kepada Tuhan. Hal ini dibuktikan dengan cara Rendra melukiskan Kristus dengan sikap yang penuh belas kasih bahkan dalam memperlakukan seorang pelacur. Pelukisan yang baik mengenai Kristus dalam puisi Rendra ini memperlihatkan betapa Rendra mempercayai, mengagungkan, serta setia kepada Kristus.

Pandangan dunia pengarang dalam puisi Khotbah, puisi ini sama halnya dengan puisi Nyanyian Angsa menunjukan gugatan Rendra terhadap lembaga agama yang menurutnya hanya memiliki sifat hubungan vertikal dan bukan horisontal. Sehingga urusan-urusan kemasyarakatan nampak diabaikan oleh para petinggi agama. Pandangan ini juga dipengaruhi pengalaman Rendra selama berada di Amerika. Ia secara langsung mengamati bahkan berada dalam suatu perubahan sosial yang tidak saja menyangkut nilai-nilai kemasyarakatan, tetapi juga keagamaan.

AKSIS: Jurnal Pendidikan Bahasa dan Sastra Indonesia Volume 1 Nomor 1, Juni 2017 e-ISSN: 2580-9040 


\section{KESIMPULAN}

Setelah dilakukan kajiaan terhadap kumpulan puisi Blues Untuk Bonnie karya Rendra dengan menggunakan pendekatan strukturalisme genetik Goldmann, dapat dilihat bagaimana pandangan dunia pengarang secara utuh. Terdapat fakta-fakta kemanusiaan yang mempengaruhi puisi-puisi yang terdapat dalam kumpulan puisi Blues untuk Bonnie karya Rendra. Fakta kemanusiaan tersebut yaitu keadaan sosial masyarakat Indonesia pada masa Orde Lama khususnya sekitar peristiwa G30S, perpindahan kekuasaan dari Soekarno ke Soeharto, keadaan sosial politik Indonesia di bawah pemerintahan Orde Baru, dekade perubahan sosial menyangkut pergerakan AfroAmerika, revolusi generasi muda, dan kontrakultur dalam masyarakat Amerika. Posisi kepenyairan Rendra juga termasuk dalam fakta kemanusiaan yang berpengaruh antara lain mengenai keterlibatannya dalam Manifesto Kebudayaan, gugatannya terhadap lembaga agama, dan kritiknya terhadap keadaan sosial masyarakat termasuk di dalamnya budaya. Peristiwa-peristiwa tersebut memiliki struktur yang sama dengan puisi-puisi yang terdapat dalam kumpulan puisi Blues Untuk Bonnie. Masing-masing puisi menggambarkan peristiwa yang ditunjukkan oleh relasi antar tokoh ataupun tokoh dengan lingkungan sekitarnya.

Struktur masyarakat pada saat kumpulan puisi Blues untuk Bonnie diciptakan berhomologi dengan struktur teks puisi. Melalui puisi-puisinya Rendra sebagai subjek kolektif mengaspirasikan apa yang terdapat dalam masyarakatnya, inilah yang disebut sebagai pandangan dunia. Pandangan dunia yang termuat dalam kumpulan puisi Blues untuk Bonnie antara lain sebagai berikut: terdapat enam puisi yang memuat pandangan dunia pengarang berupa kritik sosial terhadap keadaan sosial politik baik di Indonesia maupun Amerika. Puisi mengenai Indonesia yaitu Kupanggili Namamu, Kesaksian 
Tahun 1967, Pemandangan Senjakala, Bersatulah Pelacur-pelacur Kota Jakarta, melalui puisi-puisi ini menggambarkan keadaan Indonesia yang sulit dan menggambarkan kondisi banyak pejabat pemerintah melakukan korupsi dan pelanggaran hak asasi sehingga masyarakat hidup dalam kemiskinan dan diskriminasi hak. Kekacauan keadaan politik di Indonesia dalam pandangan Rendra adalah sesuatu yang sengaja diciptakan untuk kepentingan pihak tertentu. Sedangkan puisi Blues Untuk Bonnie memuat pandangan Rendra mengenai rasisme dan diskriminasi terhadap AfroAmerika yang menimbulkan kesengsaraan dan penderitaan bagi Negro.

Lima puisi lainnya memuat pandangan dunia pengarang mengenai pemberontakan manusia terhadap nila-nilai kebudayaan yaitu Kepada M.G, Nyanyian Duniawi, Nyanyian Suto Untuk Fatima dan Nyanyian Fatima Untuk Suto, Rick dari Corona. Dalam puisi-puisi ini ada kesamaan pola, yaitu pembicaraan mengenai ketidakpuasan tterhadap keadaan, terhadap nilai dan budaya dan digambarkan melalui perilaku seks. Dua puisi terakhir adalah tentang kritik Rendra terhadap lembaga agama yaitu Nyanyaian Angsa dan Khotbah. Dalam kedua puisi ini Rendra mengutarakan kritiknya mengenai buruknya pelayanan lembaga agama yang kurang memerhatikan kepentingan umatnya. Penelitian mengenai pandangan dunia pengarang dalam kumpulan puisi Blues untuk Bonnie ini dapat dijadikan sebagai bahan referensi pembelajaran menulis puisi di sekolah. Lingkungan sekitar dan keadaan sosial masyarakat dapat dijadikan salah satu sumber inspirasi bagi siswa dalam menciptakan puisi, sebagaimana ditunjukkan dalam penelitian ini. 


\section{UCAPAN TERIMA KASIH}

Ucapan terima kasih penulis sampaikan kepada segala pihak yang telah mendukung proses penelitian dan penulisan artikel ilmiah ini.

\section{DAFTAR PUSTAKA}

Teeuw, A. (2016). Sastra dan ilmu sastra. Bandung: Pustaka Jaya.

Damono, S. D. (1984). Sosiologi sastra: Sebuah pengantar ringkas. Jakarta: Pusat Pembinaan dan Pengembangan Bahasa Depdikbud.

Junus, U. (1974). Perkembangan novel-novel Indonesia. Kuala Lumpur: Universiti Malaya.

Pradopo, R. D. (2002). Pengkajian puisi. Yogyakarta: Gadjah Mada University Press.

Rendra, W.S. (1993). Blues untuk Bonnie. Jakarta: Pustaka Jaya.

Saini, K.M. (1993). Puisi dan beberapa masalahnya. Bandung: ITB Press. 